\title{
Utilization of home remedies to relieve Nausea and Vomiting among Pregnant Women
}

\author{
Dr. Seham Shehata Ibrahim; Dr. Reda Ibrahim El-Mowafy
}

Department of Maternity, Gynecology \& Obstetric Nursing, Faculty of Nursing, Port Said University, Egypt** Family and Community Health Nursing Department Port

Said University, Egypt

\begin{abstract}
Background: Nausea and vomiting affect a large proportion of women in early pregnancy, yet because it is a physiological symptom it is often missed by health professionals, leaving women to find their own coping mechanisms. Many pregnant women try a range of complementary and alternative therapies and natural remedies. Aim: aim of the study was to assess home remedy utilized to relieve nausea and vomiting among pregnant women. Subjects and Methods: A descriptive cross sectional study design was adopted in this study among two hundred pregnant women attending antenatal clinics for follow- up in the 6 Maternal and Child Health Centers $(\mathrm{MCH})$ in Port-Said City. A specially designed questionnaire was used to collect the data in the period between January and May 2014. Results: More than fifty of the users reported utilizing home remedies during pregnancy. The most commonly used remedies were Peppermint, lemon (citrus), vegetables, and Zangabel( Ginger). Conclusion: A large percentage of the women in the study used home remedies during pregnancy. Many of them believed that home remedies are safer on the health of their fetus than medical treatment during pregnancy. Recommendations: To develop a health education program directed toward pregnant women to increase their awareness about the benefits and harms of home remedies in ante-natal care clinics especially for herbs commonly used and the importance of consultation of health care provider before taking any type of herbs during pregnancy, since many of these herbal remedies are self-prescribed based on the woman's own information or belief.
\end{abstract}

Key words: Nurse, Pregnant women, Home remedies, Nausea and Vomiting. 


\section{INTRODUCTION}

Nausea and vomiting are common problems in the first half of pregnancy ${ }^{[1]}$. Approximately $\% 80$ percent of women are influenced during pregnancy, along with significant impact on their quality of life ${ }^{[2]}$. The reason behind gestational nausea and vomiting is not well defined yet ${ }^{[1]}$. Because it is a physiological symptom, it is often missed by health professionals, leaving women to find their own coping mechanisms. This makes many of them to try a range of complementary and alternative therapies and natural remedies, although the evidence of efficacy is variable. Furthermore, while women realize the possible risks of taking medication during pregnancy they do not see complementary medicine in the same way ${ }^{[3]}$.

A home remedy is a treatment to cure a disease or ailment that employs certain spices, vegetables, or other common items. Home remedies may or may not have medicinal properties that treat or cure the disease or ailment in question, as they are typically passed along by lay a person (which has been facilitated in recent years by the Internet). Many are merely used as a result of tradition or habit or because they are effective in inducing the placebo effect ${ }^{[4]}$.

Use of herbs during pregnancy is a very interesting area; based on literature review more research is definitely needed. The prevalence of using herbal products during pregnancy varies widely and ranges from 7-55\%, these percentages depend on the geographic area surveyed and the surveyed group's socio-cultural aspect and ethnicity [5]. The physiological changes that occur in pregnant women make them try self treatment ${ }^{[6]}$. Women turn to natural herbal products rather than prescription medications, mainly because they are concerned about the safety of their fetus. A study has shown that $34 \%$ of women did not use drug treatment (vitamin B6), and $26 \%$ administered it less than the prescribed dose, and they ascribed it to lack of trust in drug safety during pregnancy and the preference of non-medical approach ${ }^{[2]}$. Yet, another study showed that $85 \%$ of midwives recommend herbal remedies, regardless of their side effects, to pregnant women for treating gestational nausea and vomiting [7]. Among the herbal medicines mentioned in recent researches to treat nausea and vomiting of pregnancy, mint can be enumerated ${ }^{[8]}$.

In addition, a study by Holst, et al., 2011 ${ }^{[9]}$ reviewed the literature on efficacy of the most commonly used herbs to enable midwives to give evidence -based information to pregnant women. They found that $57.8 \%$ of 578 participants used at least one herbal remedy during pregnancy, the most commonly used herbs and the reasons for use were 
ginger for morning sickness, nausea, vomiting and indigestion, cranberry to treat and prevent urinary tract infection, raspberry to induce and ease labor, chamomile for relaxation, sleeping aid and calming, peppermint for digestion, heart burn, nausea, and morning sickness, and Echinacea to treat and prevent cold or flu, and to boost the immune system. Altogether, 14 studies focusing on the safety and/or efficacy of these herbs in human pregnancy were identified.

Dealing with minor discomfort is the role of the nurse / midwife during the antenatal classes. Nursing intervention focusses on reducing nausea and vomiting, maintaining nutrition and fluid balance, and providing emotional support. ${ }^{[10]}$. Furthermore, midwives/nurses are important caregivers for pregnant women and should strive to give evidence-based advice on herbal use in pregnancy. If 'traditional use' is the only available information, the pregnant woman should be made aware of this to enable her to make an informed decision about the eventual use ${ }^{[9]}$.

In Egypt, there are limited data on the extent of women's use of home remedies during pregnancy to relieve nausea and vomiting. It is important to know home remedies so that proper counseling by nurse working in maternal and child health can be provided. Herbs may have unrecognized effects on pregnancy or labor, have interactions with prescribed medications and have potentially serious complications on the fetus. Therefore, the present study was designed.

\section{AIM OF STUDY:}

The aim of the present study was to assess the home remedy utilized to relieve nausea and vomiting among pregnant women.

\section{RESEARCH QUESTION:}

What are the most frequently used home remedies by pregnant women to relieve nausea and vomiting during pregnancy?

\section{SUBJECTS AND METHODS:}

\section{Study design:}

A descriptive cross sectional study design was adopted in this study.

\section{Setting:}

This study was conducted in 6 Maternal and Child Health Centers (MCH), namely ( El-Kabouty, EL-Monakh, El-Kuwait, Osman Ebn Affan, Omar Ebn El-Kattab and El- 
Arab) in Port- Said City as it was appropriate for gathering data and reflecting what actually prevailed.

\section{Sample size:}

The population of study was all pregnant women attending the antenatal clinics of the $\mathrm{MCH}$ centers for follow- up during the period of study and were eligible for inclusion criteria (primipara and multipara, their age ranged from 20 - 40 years and free from chronic diseases). The expected number of women who visit the $\mathrm{MCH}$ was around 400 women per month based on data from $\mathrm{MCH}$, and within the five months it was expected to be around 2000 women. So the sample size was $10 \%$ of the population. The estimated sample size was approximated to 200 pregnant women randomly estimated.

\section{Tool for data collection:}

A specially designed questionnaire by the researchers according to the review of literature was used to collect the data. It consisted of two sections.

\section{The first section:}

included questions regarding socio-demographic data such as: age, educational level, residence, monthly income, work, and number of children.

\section{The second section:}

inquired about the types of home remedies consumed (a list was given, including products commonly used in pregnancy according to other studies) in addition to questions regarding (dosage, route of administration, timing of administration, reasons for use, why they preferred remedy, who advised them to use home remedies, side effects and benefits).

\section{Statistical design:}

Statistical analyses were performed using Statistical Package for Social Sciences (SPSS version 18.0). Frequency and percentage were computed as continuous data. The chi-square $\left(\mathrm{x}^{2}\right)$ test was used to analyze categorical variables which were expressed as percentage values. A P-value $<0.05$ was considered statistically significant.

\section{Pilot study:}

The questionnaire was anonymous, pretested by a pilot study of $10 \%$ of sample to check the clarity, applicability, and the time required to complete the tools. According to the results obtained from the pilot study, some questions were rephrased again. 
Those who participated in the pilot study were excluded from the main study sample to assure the stability of answers.

\section{Content validity:}

Content validity of tool was ascertained by a jury of five experts from the Obstetric Nursing and Community Health Nursing. Their opinions were elicited regarding the format layout and its parts. Modifications were done according to the experts opinions.

\section{Field work and data collection:}

The pregnant women were interviewed when they visited the anti-natal clinic to get care and follow up. The relevant data were obtained from subjects of the study through face to face interview. The researchers had to ensure that all questions were properly understood and answered. The interview took approximately 10-15 minutes to complete the questionnaire. Data were collected in the period between January and May 2014, one day each week.

\section{Ethical consideration:}

The study was conducted in the antenatal unit in Maternal and Child Health Centers after having the approval from the Faculty of Nursing at Port- Said University and administrative directors of $\mathrm{MCH}$ centers. Verbal consent was obtained from participants to participate in the study. Each participant received an explanation of the purpose of the study to be familiar with the importance of her participation, and confidentially was maintained by assuring security and privacy to all participants that the data collected were used only to meet the purpose of the research.

\section{RESULTS:}

200 pregnant women who provided data suitable for analysis, age ranged from 20 to 40 years, and $116(58 \%)$ of them reported the use of home remedies to relieve nausea and vomiting during the current pregnancy.

Table (1): shows the most commonly used home remedies to relieve nausea and vomiting during pregnancy as reported by the study sample. It was noticed that $(93.1 \%, 88.8 \%$ and $87.9 \%)$ of pregnant women used Peppermint, Citrus, and Vegetables respectively to relieve nausea and vomiting during pregnancy. Also it was found that $(48.5 \%, 25 \%$ and 19\%) used Zangabel (Ginger), thyme and beans respectively.

Table(2): results showed that more than one- third of users (33.6\%) preferred to use home remedy mainly because they thought the remedy are safer than medications 
during pregnancy, while $17.2 \%$ reported that remedies were inexpensive. Also $16.4 \%$ reported that the home remedies were more effective than pharmacological drugs and $15.6 \%$ of users reported using home remedies because they were available at home as illustrated in.

Table (3): showed the source of information, the effectiveness and frequency of home remedies used among the users. Regarding the source of information, about $(37.1 \%, \&$ $12.9 \%$ ) respectively of users were based on advice as a source of information from friends or obstetrician and nurse, while $30.1 \%$ of users were based on their knowledge as a source of information. Concerning the effectiveness of various types of home remedied, (30.1\% and $40.5 \%$ ) respectively of participants believed that the home remedies had a complete and partially relief of nausea and vomiting during pregnancy. While $(29.4 \%)$ of participants believed that the home remedies were not effective to relieve nausea and vomiting during pregnancy. Regarding to the frequency of using home remedies, more than one- third of users (35.3\% and 33.6\%) respectively used home remedies when needed 2-3 times per day, (31.1\%) of them used home remedies daily.

Table (4): showed the relation between socio-demographic characteristics of the study sample \& home remedies use. A significant association was noticed between using of home remedies and level of education, and duration of pregnancy $(p<0.05)$. While there was no significant association between using of home remedies and age of participants, family income, family size, job status, number of pregnancies, and number of abortions.

Table (1) : Distribution of home remedies utilized to relieve of nausea and vomiting during pregnancy.

\begin{tabular}{|l|c|c|}
\hline \multicolumn{1}{|c|}{$\begin{array}{c}\text { Home remedies } \\
\text { popular name(English name) }\end{array}$} & No & \\
\hline No. of non-users & 84 & 42 \\
\hline No of users & 116 & 58 \\
\hline Zaater ( Thymus vulgaris) Thyme & 29 & 25 \\
Zangabel( Ginger) & 56 & 48.5 \\
Nanaa( peppermint) & 108 & 93.1 \\
Bean & 22 & 19 \\
Citrus & 103 & 88.8 \\
Vegetables & 102 & 87.9 \\
\hline
\end{tabular}


Table (2) Reasons given by participants for actually used home remedies

\begin{tabular}{|l|c|c|}
\hline Reasons for using home remedies & No. of users(116) & \% \\
\hline Availability & 18 & 15.6 \\
Safer than medications & 39 & 33.6 \\
Inexpensive & 20 & 17.2 \\
More effective than medications & 19 & 16.4 \\
Simpler, more familiar & 8 & 6.9 \\
More than one reason & 12 & 10.3 \\
\hline
\end{tabular}

Table (3) Distribution of the users according to source of information, degree of effectiveness and frequency of home remedies used

\begin{tabular}{|l|c|c|}
\hline \multicolumn{1}{|c|}{ Variable } & $\begin{array}{c}\text { No of the users } \\
(\mathbf{n = 1 1 6})\end{array}$ & $\%$ \\
\hline Source of information: & 35 & 30.1 \\
\hline My own idea(self-preference) & 21 & 18.1 \\
My family & 43 & 37.1 \\
Friends & 15 & 12.9 \\
Obstetrician and nurse & 2 & 0.8 \\
More than one source & 35 & 30.1 \\
\hline Degree of effectiveness & 47 & 40.5 \\
\hline Complete relief & 34 & 29.4 \\
Partial relief & \multicolumn{2}{|l}{} \\
No relief & 41 & 35.3 \\
\hline Frequency of used home remedies: & 36 & 31.1 \\
\hline When needed & 39 & 33.6 \\
Daily & \multicolumn{2}{|l}{} \\
2-3 times per day &
\end{tabular}


Table (4): Relation between socio-demographic characteristics and use of home remedy during pregnancy

\begin{tabular}{|c|c|c|c|c|c|}
\hline \multirow{3}{*}{$\begin{array}{l}\text { Socio-demographic } \\
\text { Characteristics }\end{array}$} & \multicolumn{4}{|c|}{ Home remedies } & \multirow{3}{*}{$P$-value } \\
\hline & \multicolumn{2}{|c|}{$\begin{array}{c}\text { Users } \\
(n=116)\end{array}$} & \multicolumn{2}{|c|}{$\begin{array}{c}\text { Non users } \\
(n=84)\end{array}$} & \\
\hline & $\mathbf{N}$ & $\%$ & $\mathbf{N}$ & $\%$ & \\
\hline \multicolumn{6}{|l|}{ Age in Years } \\
\hline $20-25$ & 50 & 43.1 & 79 & 94 & \multirow{4}{*}{0.470} \\
\hline $26-30$ & 29 & 25 & 5 & 6 & \\
\hline $31-35$ & 33 & 28.4 & 0 & 0 & \\
\hline $36-40$ & 4 & 3.5 & 0 & 0 & \\
\hline \multicolumn{6}{|l|}{ Educational level: } \\
\hline Preparatory school & 13 & 11.2 & 0 & 0 & \multirow{3}{*}{$0.009 *$} \\
\hline Secondary school & 77 & 66.4 & 73 & 86.9 & \\
\hline University & 26 & 22.4 & 11 & 13.1 & \\
\hline \multicolumn{6}{|l|}{ Occupation: } \\
\hline Worked & 107 & 92.2 & 81 & 96.4 & \multirow[b]{2}{*}{0.087} \\
\hline Housewife & 9 & 7.8 & 3 & 3.6 & \\
\hline \multicolumn{6}{|l|}{ Family income: } \\
\hline$\sim 600 \mathrm{LE}$ & 31 & 26.7 & 24 & 28.6 & \multirow[t]{3}{*}{0.151} \\
\hline 1000 LE & 81 & 69.8 & 60 & 71.4 & \\
\hline $1000 \mathrm{LE}$ & 4 & 3.5 & 0 & 0 & \\
\hline \multicolumn{6}{|l|}{ Family size: } \\
\hline 3 & 73 & 62.9 & 82 & 97.6 & \multirow[t]{2}{*}{0.708} \\
\hline $4+$ & 43 & 37.1 & 2 & 2.4 & \\
\hline \multicolumn{6}{|l|}{$\begin{array}{l}\text { Obstetric history: } \\
\text { No. of pregnancies }\end{array}$} \\
\hline Primigravida & 24 & 20.7 & 81 & 96.4 & \multirow{3}{*}{0.695} \\
\hline 2 & 57 & 49.1 & 3 & 3.6 & \\
\hline $3+$ & 35 & 30.3 & 0 & 0 & \\
\hline \multicolumn{6}{|l|}{ No of Abortions } \\
\hline 0 & 113 & 97.4 & 84 & 100 & \multirow[b]{2}{*}{0.105} \\
\hline $2+$ & 3 & 2.6 & 0 & 0 & \\
\hline \multicolumn{6}{|l|}{ Duration of pregnancy } \\
\hline $1^{\text {st }}$ trimester & 93 & 80.2 & 73 & 86.9 & \multirow{3}{*}{$0.002 *$} \\
\hline $2^{\text {nd }}$ trimester & 16 & 13.8 & 0 & 0 & \\
\hline $3^{\text {rd }}$ trimester & 7 & 6 & 11 & 13.1 & \\
\hline
\end{tabular}

*Statistically significant

\section{DISCUSSION:}

The present study aimed to assess the home remedies utilized to relieve nausea and vomiting among a sample of pregnant women attending $\mathrm{MCH}$ centers in Port-Said City. The results of the present study revealed that more than half $(58 \%)$ of users used 
one or more home remedies to relieve nausea and vomiting during pregnancy, this finding is higher than many studies from other parts of the World. As compared with other studies ${ }^{[9,11]}$, about $57.8 \%$ of pregnant women used one or more home remedies during their pregnancy.

Peppermint, lemon (citrus), vegetables and Zangabel (Ginger) respectively, were the most commonly used remedies to relieve nausea and vomiting during the pregnancy as reported by the users in the present study. This result agrees with many authors ${ }^{[\mathbf{9 , 1 2}]}$ who reported that Peppermint is used for nausea, vomiting, flatulence, indigestion and heart burn. In other studies, ginger was the most common ${ }^{[5,13,14]}$. In addition, a study conducted by Broussard ${ }^{[15]}$ revealed that ginger was also commonly used during the first trimester (53\%). Ginger (Zingiber officinale) is a well-known remedy for gestational sickness, its antiemetic effects probably being due to local gastrointestinal anti-cholinergic and antihistaminic actions ${ }^{[16]}$. Vutyavanich et al., ${ }^{[17]}$ demonstrated significant improvements in the severity of both nausea and vomiting of pregnancy. Furthermore, Fischer Rasmussen et al., ${ }^{[18]}$ found it particularly effective for hyperemesis gravidarum when compared to placebo. As regards lemon (citrus), the results of a Pretest-Posttest study in Indonesia on 12 pregnant women with nausea and vomiting during the pregnancy (NVP) showed that lemon aromatherapy reduced NVP [19], which is in agreement with the results of this study.

Despite the fact that there is a safe and effective pharmacologic treatment for (NVP), many women and their physicians are still cautious and often fearful of taking drugs during pregnancy. Occasionally, lack of treatment leads to severe hyperemesis and results in hospitalization and rehydration with intravenous fluids which has great emotional and financial costs ${ }^{[20]}$.

Among the reasons that women gave for using home remedies, the participants expressed a greater comfort level when using home remedies than pharmaceutical medicine. The results of the present study indicated that more than one- third of users (33.6\%) preferred to use home remedy mainly because they thought that they are safer than medications during pregnancy. This result is similar to Hepner, $2002^{[21]}$, who reported that reasons for using herbal medicines during pregnancy include concerns for the health of the fetus. Furthermore, the most common reasons that forced them to use herbs were that herbs have better efficacy than conventional medicine, herbs being natural are safer during pregnancy than conventional medicine, easier access to herbal medicines, traditional and cultural belief and low cost ${ }^{\text {[22] }}$. 
Regarding the source of information most of users were based on advice from friends similar to previous authors ${ }^{[23,24]}$ who reported that the sources of information were suggested by friends or family. Also the results revealed that they were based on their knowledge as a source of information which is in line with Hepner et al ${ }^{[21]}$. Finally, the rest of the study sample were based on information from obstetrician and nurse, and this result is in agreement with Hepner et al ${ }^{[21]}$ who reported that herbal use in pregnancy has been recommended by health care providers.

Concerning the effectiveness of various types of home remedies, the participants of the present study believed that home remedies were completely and partially effective to manage nausea and vomiting during pregnancy. These results are supported by Nordeng and Havnen ${ }^{[25]}$ who reported that the use of herbal medicines plays significant roles in the management of both minor and major illnesses, and it has been influenced by patients' dissatisfaction with conventional allopathic medicines in terms of effectiveness, safety and satisfaction with therapeutic outcome ${ }^{[26]}$.

Regarding socio-demographic characteristics of the sample, educational level was significantly associated with use of home remedies to relieve (NVP) $(p<0.05)$. Women with secondary school used home remedies more than women with preparatory school and university education. The preparatory educational attainment in this study group may also explain the lower prevalence of home remedies use than in other studies. The findings of other studies indicated that educational status is a consistently important factor in the use of home remedies $\underline{[27}, \underline{28}]$.

The results of the present study revealed that there was no significant association between using of home remedies, age of participants and family income. This result was supported by Gibson, et al., 2001, ${ }^{[29]}$ who reported that there was no significant association between herb use during pregnancy and age or income level.

\section{CONCLUSION:}

Based on the results of the present study, it can be concluded that a large percentage of the women in the study used home remedies to relieve nausea and vomiting during pregnancy. Many of them believed that the home remedies are safer on the health of their fetus than medical treatment during pregnancy. They believed that the home remedies have complete and partially effect on relieving nausea and vomiting. Generally, women should not use over-the-counter remedies for nausea and vomiting whilst they are pregnant because their safety and effectiveness are uncertain. 


\section{RECOMMENDATIONS:}

Based on the study findings, the following recommendations are required: A health education program directed to pregnant women should be implemented to increase their awareness about the benefits and harms of home remedies used during pregnancy in ante-natal care clinics especially for commonly used herbs and the importance of consulting health care provider before taking any types of herbs during pregnancy, since many of these herbal remedies are self-prescribed based on the woman's own information or belief. Further research on the use and patterns of use of home remedy among women during pregnancy, labor and the postpartum period, in both public and private health facilities should be extended to rural areas.

\section{ACKNOWLEDGMENTS:}

The authors would like to appreciate the directors of $\mathrm{MCH}$ centers for their support to conduct the study, and all who sincerely cooperated in the study.

\section{REFERENCES:}

Cunningham FG, Leveno KJ, Bloom SL, Hauth JC, Rouse DJ, Spong CY. Prenatal Care. (2010): In: Cunningham FG, Leveno KJ, Bloom SL, Hauth JC, Gilstrap LC, Wenstrom KD, editor(s). Williams Obstetrics: 23rd Edition. McGraw-Hill.

Baggley A, Navioz Y, Maltepe C, Koren G, Einarson A. (2004): Determinants of women's decision making on whether to treat nausea and vomiting of pregnancy pharmacologically. J Midwifery Womens Health. 49(9):350-4.

Tiran D. (2002): Nausea and vomiting in pregnancy: safety and efficacy of selfadministered complementary therapies. Complement Ther Nurs Midwifery, Nov.,8(4):191-6 "Placebo Effect: A Cure in the Mind". Scientific American. February-March 2009.

Dugoua, J J. (2010): Herbal medicines and pregnancy. Journal of Population and Therapeutics and Clinical Pharmacology, 17(3): 370-8.

Holst L, Wright D, Haavik S, Nordeng H. (2009): The use and the user of herbal remedies during pregnancy. Journal of Alternative and Complementary Medicine, 15(7): 787-92.

Wills $G$, Forster D. (2008): Nausea and vomiting in pregnancy: what advice do midwives give? Midwifery, 24(4):390-8.

Gilligan N. The palliation of nausea in hospice and palliative care patients with essential oils of Pimpinella anisum (aniseed), Foeniculum vulgare var. dulce (sweet 
fennel), Anthemis nobilis (Roman chamomile) and Mentha x piperita (peppermint). Int J Aromatherapy. 2005;15(4):163-7.

Holst L, Wright D, Haavik S, Nordeng H. (2011): Safety and efficacy of herbal remedies in obstetrics-review and clinical implications. Midwifery, 27(1): 80-86.

Greene A. Nausea and vomiting symptom, causes, and test-NY time health information, available at 31-1-2010, http:// health-nytime.com /health / guide / symptoms / nausea-and-vomiting / overview.html.

AB. Rahman A. (2008): Prevalence and pattern of use of Herbal Medicine during pregnancy in Tumpat district, Kelantan. Malaysian Journal of Medical Sciences, July, 15(3): 40-8.

Henry A, Crowther C. (2000): Patterns of Medication use during and prior to pregnancy: the MPA study. Australian and New Zealand Journal of Obstetrics and Gynecology, 40(2): 165-172.

Ebrahimi N, Maltepe C, Einarson A. (2010): Optimal management of nausea and vomiting of pregnancy. International Journal of Women's Health, 2: 241-248.

Nordeng H, Bayne K, Havnen G C, Paulsen B S. (2011): Use of herbal drugs during pregnancy among 600 Norwegian women in relation to concurrent use of conventional drugs and pregnancy outcome. Complementary Therapies in Clinical Practice, 17(3):147-151.

Broussard CS, Louik C, Honein M A, Mitchell A A. (2010): Herbal use before and during pregnancy. American Journal of Obstetrics and Gynecology, 202(5): 443.e1-6.

Quian DS, Liu ZS. (1992): Pharmacologic studies of anti- motion sickness actions of ginger. Chung Kuo Chung His Chieh Ho Tsa Chih, 12:95-8.

Vutyavanich T, Kraisarin T, Ruangsri R. (2001): Ginger for nausea and vomiting in pregnancy: randomized double-masked, placebo controlled trial. Obstet Gynecol, 97(4):577-82.

Fischer Rasmussen W. (1991): Ginger treatment of hyperemesis gravidarum. Eur J Obstet Gynecol Reprod Biol, 38:19.

Auwaliyah F. 2010. Available from:

http://alumni.unair.ac.id/kumpulanfile/6054832618 7 http://alumni.unair.ac.id/kumpulanfile/6054832618.

Chandra K, Einarson A, Koren G. (2002): Taking ginger for nausea and vomiting during pregnancy, Canadian Family Physician, September Vol 48, 1441-2. 
Hepner DL, Harnett M, Segal S, Camann W, Bader AM, Tsen LC. (2002): Herbal medicine use in parturients. Anesth Analg, 94(3):690-3.

Willetts KE, Ekangki A, Eden JA. (2003): Effect of ginger extract on pregnancyinduced nausea. Aust N Z J Obstet Gynecol, 43(2):139-44.

Fakeye T O, Adisa R, Musa I E. (2009): Attitude and use of herbal medicine among pregnant women in Nigeria. BMC Complementary and Alternative Medicine, 9: 53.

Maats F, Crowther C. (2002): Patterns of vitamin, mineral and herbal supplement use prior to and during pregnancy. Aust N Z J Obstet Gynaecol, 42:494-6.

Nordeng H, Havnen G. (2004): Use of herbal drugs in pregnancy: a survey among 400 Norwegian women. Pharmaco Epidemiol Drug Saf., 13:371-80.

Barnes J. Quality, efficacy and safety of complementary medicines: fashions, facts and the future. Part1. Regulation and quality. (2003): Br J Clin Pharmacol, 55(3):22633.

Addo VN. (2007): Herbal Medicines: Socio-demographic Characteristics and Pattern of Use by Patients in a Tertiary Obstetrics and Gynaecology Unit. J Sci Technol. 27(3):149-160.

Tamuno I, Omole-Ohonsi A, Fadare J. (2011): Use of Herbal Medicine Among Pregnant Women Attending A Tertiary Hospital In Northern Nigeria. Intern J of Gyn and Obstet. 15(2).

Gibson SP, Powrie R, Star J. (2001): Herbal and alternative medicine use during pregnancy: a cross-sectional survey. April, Obstetrics \& Gynecology, 97( 4):Supp(1): S44-S45. 


\title{
استخام العلاجات المنزلية لتخفيف الغثيان والقيء لاى الحوامل
}

\author{
د. سهام إبر اهيم شحاتة د. رضا إبر اهيم المو افي \\ قسم تمريض الأمومة و أمر اض النساء ،قسم تمريض الأسرة و صحة المجتمع ـكلية التمريض - جامعة \\ بورسعيد، مصر الأنرة
}

\section{الخلاصه}

يؤثر الغنيان و القيء على نسبة كبيرة من النساء في مرحلة مبكرة من الحمل، و لأنه عرض من الأعر اض الفسيولوجية في كثير من الأحيان يتم صرف النظر عنه من قبل المهنيين الصحيين، وترك النساء لإيجاد آليات مئه التكيف الخاصة بهم. وهذا يؤدي إلى تجربة الكثير منهم مجموعة من العلاجات التكميلية والبديلة و العلاجات الطبيعية.

الهدف: تقييم العلاجات المنزلية المستخدمة لتخفيف الغثيان و القيء لدى الحو امل.

أدوات البحث: تم استخدام در اسة مستعرضة(قطعية) وصفية لتحقيق الهدف من هذه الدر اسة بين مائتي من النساء

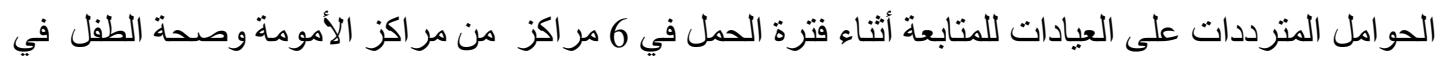
مدينة بورسعيد. تم استخدام استمارة استبيان مصممة خصيصا لجمع البيانات في الفترة ما بين يناير ومايو 2014.

النتائج: أكثر من خمسين في المائة من المشاركين استخدمو الأعشاب خلال فترة الحمل. ويعتقد (30.1٪ و 40.5٪) من المشاركين أن العلاجات المنزلية كانت بالكامل وجزئيا فعالة لعلاج الغثيان و القيء خلال فترة الحمل ولى على التو الي. بالإضافة إلى ذلك، لوحظ أن هناك علاقة وثيقة بين استخدام العلاجات المنزلية و التعليم،ومدة الحمل

الاستنتاجات: لقد تبن أن هناك نسبة كبيرة من النساء الحو امل استخدمو ا العلاجات المنزلية خلال فترة الحمل . ويعتقد كثير منهم أن العلاجات المنزلية أكثر أمانا على صحة الجنين بهم من العلاج الطبي أثناء الحمل ـويعتقدون أن العلاجات المنزلية لها تأثير كامل وجزئي في تخفيف الغتيان و القيء .عموما، يجب على النساء عدم استخدام أكثر من وصفة لعلاج الغثيان و القيء في حين أنهن حوامل .وذللك لأن سلامة وفعالية هذه العلاجات للغثيان و القيء خلال فترة الحمل غير مؤكدة.

التوصيات: هناك حاجة إلى إعداد برنامج تثقيفية صحية موجهة نحو النساء الحو امل لزيادة و عيهم حول فو ائد ومضار العلاجات المنزلية في عيادات الرعاية ما قبل الولادة وخاصة بالنسبة للعلاجات المنزلية التي يشيع

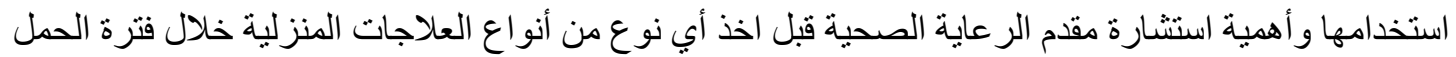
، لأن العديد من هذه العلاجات المنزلية تستخدم عليها على معلومات المر أة الخاصة أو معتقداتها.

الكلمات السترشاديةة: ممرضة، النساء الحو امل، العلاجات المنزلية، و الغثيان و القيء. 